\title{
Treatment of acute appendicitis: Urgent surgery or emergent surgery?
}

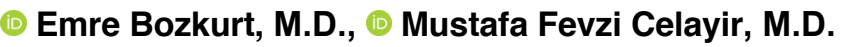

Department of General Surgery, University Of Health Sciences, Şişli Hamidiye Etfal Training and Research Hospital, İstanbul-Turkey

\begin{abstract}
BACKGROUND: The standard treatment of acute appendicitis, which is a rapidly progressive inflammatory disease, remains surgery. However, several studies have suggested antibiotics treatment for acute appendicitis, especially in centers where surgery at all hours is not possible. Therefore, in this study, we investigated the relationship between the preoperative waiting period and postoperative complications in patients who underwent interval surgery following conservative management during the same admission.

METHODS: All patients who were diagnosed with uncomplicated acute appendicitis between October 2014 and February 2015 and underwent surgery at a single center were included in this retrospective study. Patients were divided into two groups based on the waiting period between the diagnosis and the time of surgery: group A (emergency, waiting period $<10 \mathrm{~h}$ ) and group B (urgency, waiting period $\geq 10 \mathrm{~h}$ ). The demographic features, preoperative waiting period, antibiotics use, pathological diagnosis, postoperative complications, length of hospital stay, and readmission were compared between the two groups.

RESULTS: This study comprised 160 patients, including 79 and 81 patients in groups $A$ and $B$, respectively. The demographic features, comorbidities, and pathological diagnosis were comparable between the two groups. The average preoperative waiting period was significantly longer in group B than in group A. However, the mean length of hospital stay and the rate of postoperative complications, including infections at the surgical sites and intra-abdominal abscesses, were similar between the two groups.
\end{abstract}

CONCLUSION: Our analyses revealed that there were no disadvantages associated with a longer preoperative waiting period in patients diagnosed with uncomplicated appendicitis.

Keywords: Appendicitis; delayed appendectomy; medical therapy; uncomplicated appendicitis.

\section{INTRODUCTION}

Acute appendicitis (AA) is the most common cause of acute abdomen, ${ }^{[1]}$ for which standard therapy is surgery; the mortality rate of $\mathrm{AA}$ ranges between $0.07 \%$ and $0.7 \% .^{[2,3]}$ The mechanism underlying $A A$ includes abdominal wall necrosis following a decrease in blood and lymph flow after luminal obstruction, and the delayed diagnosis of AA leads to perforation. Although emergent surgical intervention is considered to prevent the progression of $A A$, the effects of emergent appendectomy on morbidity and mortality have been reported to have limited benefits based on accumulating evidence. In addition, recent reports regarding pediatric patients have indicated that surgical treatment can be safely postponed with effective fluid and antibiotic therapy. ${ }^{[4-6]}$ Therefore, the waiting period is considered to not contribute to increased morbidity in patients who have to wait for mandatory reasons.

We, therefore, investigated whether $A A$ in adult patients was a surgical emergency requiring immediate intervention and assessed the relationship between preoperative waiting time and postoperative complications.

\section{MATERIALS AND METHODS}

This retrospective study included all the patients who were diagnosed with uncomplicated AA between October 2014 and February 2015 at the study institution. Ethics approv-

Cite this article as: Bozkurt E, Celayir MF. Treatment of acute appendicitis: Urgent surgery or emergent surgery?. Ulus Travma Acil Cerrahi Derg 2020;26:742-745.

Address for correspondence: Emre Bozkurt, M.D.

Sağlık Bilimleri Üniversitesi, Şişli Hamidiye Etfal Eğitim ve Araştırma Hastanesi, Genel Cerrahi Kliniği, İstanbul, Turkey

Tel: +90 212 - 3735000 E-mail: dr.emrebozkurt@gmail.com

Ulus Travma Acil Cerrahi Derg 2020;26(5):742-745 DOI: 10.14744/tjtes.2020.23236 Submitted: 05.12.2019 Accepted: 13.06.2020 Online: 09.09.2020

Copyright 2020 Turkish Association of Trauma and Emergency Surgery 
al was not required for this retrospectively designed study (analysing of pre-existing data). This study was conducted in accordance with the 1964 Helsinki Declaration. Informed consent was obtained from all subjects, and all methods were carried out in accordance with the relevant guidelines and regulations. While the inclusion criteria were as follows: (I) age between 18-65 years, (2) no additional comorbidity, (3) patients with final pathological diagnosis as AA, the exclusion criteria were as follows: (I) age, <18 years or >66 years; (2) patients undergoing additional surgical procedures concomitantly with appendectomy; (3) pregnancy; (4) requirement for intensive care; and (5) patients with incidental, interval, and negative appendectomies. Demographical data, comorbidities, the time interval between the diagnosis and surgery, operation time, length of hospital stay, antibiotics use, analgesic requirement, pathological diagnosis, and readmission status were included.

On the basis of our review of similar studies, the patients who fulfilled the inclusion and exclusion criteria were classified into the following two groups: group A comprising patients with a preoperative waiting time of $<10 \mathrm{~h}$ (emergent appendectomy) and group B comprising patients with a preoperative waiting time of $\geq 10 \mathrm{~h}$ (urgent appendectomy). The patient characteristics were compared between the two groups. Antibiotic prophylaxis was performed with I-g cefazolin sodium (Mustafa Nevzat, Istanbul, Turkey) within one $h$ of the AA diagnosis in all patients.

The results were analyzed using SPSS version 21.0 (IBM, Armonk, NY, USA). Continuous variables were expressed as means \pm standard deviation (SD) or medians (range) on the basis of data distribution, whereas categorical variables were presented as absolute values and percentages. Differences in continuous variables between the two groups were assessed using Student's t-test for normally distributed variables and the Mann-Whitney $U$ test for non-normally distributed variables. Differences in categorical variables were assessed using Fisher's exact or chi-square tests. A P-value of less than 0.05 was considered to indicate statistical significance.

\section{RESULTS}

A total of 160 patients diagnosed with AA between October 2014 and February 2015 and fulfilled the study criteria were included in the present study. Groups A and B included 79 and $8 \mathrm{I}$ patients, respectively, with $\mathrm{F} / \mathrm{M}$ ratios of $23 / 56$ and $27 / 54$, respectively. The mean ages were $31.9 \pm 11.5$ (range, $18-66$ ) and $30.8 \pm 8.8$ (range, 18-65) years in groups $A$ and $B$, respectively $(p=0.882)$. No significant difference was noted in the comorbidity rates between the two groups $(p=0.339)$. In groups $A$ and $B$, the mean preoperative waiting periods were 4.4 2.0 (range, I-9) and I5.I \pm 4.3 (range, I0-32) h $(p<0.00 \mathrm{I})$, and the mean operation times were $50.3 \pm 16.2$ (range, 20-90) and 54.0 12.6 (range, 20-80) $\min (p=0.040)$, respectively. The mean length of hospital stay was $30.4 \pm 13.5$ (range, 8-96) $\mathrm{h}$ in group $\mathrm{A}$ and $30.3 \pm 8.3$ (range, $\mathrm{Il}-48$ ) $\mathrm{h}$ in group $B(p=0.391)$ (Table I).

Wound infections were observed in three patients $(3.8 \%)$ in group $A$ and in five patients $(6.17 \%)$ in group $B$, which did not significantly differ between the two groups $(p=0.720)$.

Table I. Comparison of the surgical details between the two study groups

\begin{tabular}{|c|c|c|c|c|c|}
\hline & \multicolumn{2}{|c|}{ Group A } & \multicolumn{2}{|c|}{ Group B } & \multirow[t]{2}{*}{$\mathbf{p}$} \\
\hline & Mean \pm SD & Min-Max & Mean $\pm S D$ & Min-Max & \\
\hline Preoperative waiting period $(h)$ & $4.4 \pm 2.0$ & $1-9$ & $15.1 \pm 4.3$ & $10-32$ & $<0.001$ \\
\hline Operation time (min) & $50.3 \pm 16.2$ & $20-90$ & $54.0 \pm 12.6$ & $20-80$ & 0.040 \\
\hline Hospital stay (h) & $30.4 \pm 13.5$ & $8-96$ & $30.3 \pm 8.3$ & $11-48$ & 0.391 \\
\hline
\end{tabular}

Table 2. Comparison of the postoperative features between the two study groups

\begin{tabular}{|c|c|c|c|c|c|}
\hline & \multicolumn{2}{|c|}{ Group A } & \multicolumn{2}{|c|}{ Group B } & \multirow[t]{2}{*}{$\mathbf{p}$} \\
\hline & n (79) & $\%$ & n (8I) & $\%$ & \\
\hline In-hospital SSIs & 3 & 3.8 & 5 & 6.2 & 0.720 \\
\hline Intra-abdominal abscess & - & - & 2 & 2.5 & 0.497 \\
\hline Antibiotic use & 79 & 100 & 80 & 98.8 & 1.000 \\
\hline Narcotic analgesic requirement & 7 & 8.9 & 9 & II.I & 0.343 \\
\hline
\end{tabular}


Furthermore, the intra-abdominal abscesses, which were observed only in two patients in group $B$, did not significantly differ between the two groups $(p=0.497)$. No significant differences were noted in the rates of antibiotic and analgesic use between the two groups $(p=1.000$ and 0.343 , respectively) (Table 2).

According to the pathological assessment, 75 (94.9\%), three (3.8\%), and one ( $1.3 \%$ ) patient in group $A$ received the definitive diagnoses of AA, lymphoid hyperplasia, and mucinous neoplasia, respectively. In group B, 78 (96.3\%) and three $(3.7 \%)$ patients were definitively diagnosed with AA and lymphoid hyperplasia, respectively, based on the pathological assessment. No significant difference was noted in the distribution of the definitive diagnoses between the two groups $(p=0.837)$.

\section{DISCUSSION}

Appendectomy is the most frequently performed emergency surgery by general surgeons. ${ }^{[7,8]}$ Following diagnosis, patients are usually treated within a few hours for preventing the progression of inflammation. Studies have shown that AA can be treated without interval appendectomy, especially in patients with plastron appendicitis. ${ }^{[9-11]}$ Antibiotic therapy has also been demonstrated to be successful without surgery in select cases of uncomplicated AA. ${ }^{[12,13]}$

The ideal timing for surgery in patients who require surgery remains a focus of debate. Certain studies have suggested that the outcomes are better with emergent appendectomy than with delayed appendectomy. ${ }^{[13-17]}$ In contrast to these studies suggesting that delayed surgery for appendicitis is associated with increased rates of postoperative complications, such as surgical site infections, other studies have reported no significant differences in the complication rates between early and late appendectomies. ${ }^{[4,18,19]}$ Moreover, some studies have shown that fatigue and the lack of sleep adversely affect the clinical performance and cognitive skills of the surgeons during immediate appendectomies performed at night or at the end of long shifts in the operating room, leading to an increase in complication rates. ${ }^{[20,21]}$

In the present study, we found that delaying the surgery for several reasons (fasting status of the patient and the order of urgency of waiting operations) following the diagnosis of $A A$ in the emergency department was not associated with increased complication rates or increased length of hospital stay. One likely explanation for these findings is the initiation of treatment with antibiotics and fluid support in patients with a waiting period of more than $10 \mathrm{~h}$, which may allow the control of inflammation. Accordingly, no significant differences were noted in the rates of postoperative surgical site infections or intra-abdominal abscesses between the patients treated with emergency surgery and patients treated with urgent surgery. However, Busch et al. ${ }^{[22]}$ reported that an in-hospital delay of more than $12 \mathrm{~h}$ was associated with increased rates of perforation and other complications. Furthermore, Teixeira et al. ${ }^{[13]}$ reported that an in-hospital delay of more than six $h$ led to an increased surgical site infection rate independently of other factors. Giraudo et al. ${ }^{[17]}$ reported a significant increase in the complication rates between the delayed $(\geq 24 \mathrm{~h})$ and early $(<24 \mathrm{~h})$ appendectomy groups. However, two other retrospective studies reported that no significant differences were noted in the complication rates between the early $(<12 \mathrm{~h})$ and late $(12-24 \mathrm{~h})$ groups. ${ }^{[5,23]} \mathrm{A}$ meta-analysis found that delays over $48 \mathrm{~h}$ were associated with increased wound infection rates. ${ }^{[24]}$

Patients with AA can wait for more than $10 \mathrm{~h}$ for surgery at our center, which is a high-volume trauma center with a 24-hour surgical team on duty. Patients with AA can be maintained with fluid resuscitation and intravenous antibiotic therapy, excluding patients with perforation, who are pregnant, and those exhibiting sepsis symptoms. No differences were noted in the patient outcomes, complications, and the length of hospital stay between the patients treated with emergency surgery and patients treated with urgent surgery. In conclusion, patients receiving antibiotic and fluid therapy, with the exclusion of high-risk patients, can be safely maintained for up to $24 \mathrm{~h}$ although AA requires surgery. These findings derived from retrospective data should be substantiated in prospective studies.

Peer-review: Internally peer-reviewed.

Authorship Contributions: Concept: E.B., M.F.C.; Design: E.B., M.F.C.; Supervision: E.B., M.F.C.; Fundings: E.B., M.F.C.; Materials: E.B., M.F.C.; Data: E.B., M.F.C.; Analysis: E.B., M.F.C.; Literature search: E.B., M.F.C.; Writing: E.B., M.F.C.; Critical revision: E.B., M.F.C.

Conflict of Interest: None declared.

Financial Disclosure: The authors declared that this study has received no financial support.

\section{REFERENCES}

1. Humes DJ, Simpson J. Acute appendicitis. BMJ 2006;333:530-4.

2. Blomqvist P, Ljung H, Nyrén O, Ekbom A. Appendectomy in Sweden 1989-1993 assessed by the Inpatient Registry. J Clin Epidemiol 1998;51:859-6\$. [CrossRef]

3. Margenthaler JA, Longo WE, Virgo KS, Johnson FE, Oprian CA, Henderson WG, et al. Risk factors for adverse outcomes after the surgical treatment of appendicitis in adults. Ann Surg 2003;238:59-66. [CrossRef]

4. Yardeni D, Hirschl RB, Drongowski RA, Teitelbaum DH, Geiger JD, Coran AG. Delayed versus immediate surgery in acute appendicitis: do we need to operate during the night: J Pediatr Surg 2004;39:464-9.

5. Surana R, Quinn F, Puri P. Is it necessary to perform appendicectomy in the middle of the night in children?. BMJ 1993;306:1168 [CrossRef]

6. Bachoo P, Mahomed AA, Ninan GK, Youngson GG. Acute appendicitis: the continuing role for active observation. Pediatr Surg Int 2001;17:125-8 [CrossRef]

7. Pittman-Waller VA, Myers JG, Stewart RM, Dent DL, Page CP, Gray GA, et al. Appendicitis: why so complicated? Analysis of 5755 consecu- 
tive appendectomies. Am Surg 2000;66:548-54.

8. Lee HJ, Park YH, Kim JI, Choi PW, Park JH, Heo TG, et al. Comparison of clinical outcomes and hospital cost between open appendectomy and laparoscopic appendectomy.J Korean Surg Soc 2011;81:321-5 [CrossRef]

9. Andersson RE, Petzold MG. Nonsurgical treatment of appendiceal abscess or phlegmon: a systematic review and meta-analysis. Ann Surg 2007;246:741- [CrossRef]

10. Lugo JZ, Avgerinos DV, Lefkowitz AJ, Seigerman ME, Zahir IS, Lo AY, et al. Can interval appendectomy be justified following conservative treatment of perforated acute appendiciti ? J Surg Res 2010;164:91-4.

11. Kaya C, Demir U, Arısoy M, Okul Ş, Bostancı Ö, Köksal HM, et al. Does interval appendectomy necessary for the patients diagnosed as appendicular masses? SETB 2012;46:189-92.

12. Sakorafas GH, Mastoraki A, Lappas C, Sampanis D, Danias N, Smyrniotis V. Conservative treatment of acute appendicitis: heresy or an effective and acceptable alternative to surgery?. Eur J Gastroenterol Hepatol 2011;23:121-7, [CrossRef]

13. Teixeira PG, Sivrikoz E, Inaba K, Talving P, Lam L, Demetriades D. Appendectomy timing: waiting until the next morning increases the risk of surgical site infections. Ann Surg 2012;256:538-43 [CrossRef]

14. Udgiri N, Curras E, Kella VK, Nagpal K, Cosgrove J. Appendicitis, is it an emergency?. Am Surg 2011;77:898-901.

15. Ditillo MF, Dziura JD, Rabinovici R. Is it safe to delay appendectomy in adults with acute appendicitis?. Ann Surg 2006;244:656-60 [CrossRef]

16. Earley AS, Pryor JP, Kim PK, Hedrick JH, Kurichi JE, Minogue AC, et al. An acute care surgery model improves outcomes in patients with appendicitis. Ann Surg 2006;244:498-504.

17. Giraudo G, Baracchi F, Pellegrino L, Dal Corso HM, Borghi F. Prompt or delayed appendectomy? Influence of timing of surgery for acute appendicitis. Surg Today 2013;43:392-6 [CrossRef]

18. Nagpal K, Udgiri N, Sharma N, Curras E, Cosgrove JM, Farkas DT. Delaying an appendectomy: is it safe? Am Surg 2012;78:897-900. [CrossRef]

19. Stahlfeld K, Hower J, Homitsky S, Madden J. Is acute appendicitis a surgical emergency?. Am Surg 2007;73:626-3 p. [CrossRef]

20. Eastridge BJ, Hamilton EC, O'Keefe GE, Rege RV, Valentine RJ, Jones DJ, et al. Effect of sleep deprivation on the performance of simulated laparoscopic surgical skill. Am J Surg 2003;186:169-74. [CrossRef]

21. Kahol K, Leyba MJ, Deka M, Deka V, Mayes S, Smith M, et al. Effect of fatigue on psychomotor and cognitive skills. Am J Surg 2008;195:195-204. [CrossRef]

22. Busch M, Gutzwiller FS, Aellig S, Kuettel R, Metzger U, Zingg U. In-hospital delay increases the risk of perforation in adults with appendicitis. World J Surg 2011;35:1626-33. [CrossRef]

23. Abou-Nukta F, Bakhos C, Arroyo K, Koo Y, Martin J, Reinhold R, et al. Effects of delaying appendectomy for acute appendicitis for 12 to 24 hours. Arch Surg 2006;141:504-6; discussioin 506-7 [CrossRef]

24. United Kingdom National Surgical Research Collaborative, Bhangu A. Safety of short, in-hospital delays before surgery for acute appendicitis: multicentre cohort study, systematic review, and meta-analysis. Ann Surg 2014;259:894-903.

\section{ORİJINAL ÇALIŞMA - ÖZET}

\section{Akut apandisit tedavisinde acil cerrahi veya gecikmiş cerrahinin yeri Dr. Emre Bozkurt, Dr. Mustafa Fevzi Celayir}

Sağlık Bilimleri Üniversitesi, Şişli Hamidiye Etfal Eğitim ve Araştırma Hastanesi, Genel Cerrahi Kliniği, İstanbul

AMAÇ: Akut apandisit, hızla ilerleyen bir iltihabi hastalık olup, standart tedavisi acil cerrahi girişimdir. Bununla birlikte, son zamanlarda bazı olgularda yarı elektif olarak apendektomi planlanabileceği konusunda görüşler belirtilmektedir. Bu çalışmamızdaki amacımız zorunlu nedenlere bağlı ameliyatın ertelendiği durumlarda ve komplike olmayan olgularda sıvı ve antibiyotik tedavisi altında güvenli olarak apendektomi uygulanabileceğini ortaya koymaktır.

GEREÇ VE YÖNTEM: Çalışmamız Ekim 20।4-Şubat 2015 tarihleri arasında akut apandisit ön tanısı ile apendektomi yapılmış 160 olguyu içermektedir. Hastalar, ameliyat öncesi bekleme süresi 10 saat altı ve üstü olacak şekilde iki gruba ayrıldı ve patoloji sonuçları, komplikasyon oranları ve hastanede kalış sürelerine göre karşılaştıııldı.

BULGULAR: Çalışmaya 160 hasta alındı. Grup A'da 79, Grup B'de 8 I hasta vardı. Hastaların demografik verileri, patoloji raporları ve komorbid durumları incelendiğinde istatistiksel anlamlı fark yoktu. Ortalama ameliyat öncesi bekleme süresi ve ameliyat süreleri karşılaştırıldığında gruplar arasında anlamlı fark saptandı. Hastaneden kalış süreleri, yara yeri enfeksiyonu ve karıniçi apse açısından her iki grup arasında anlamlı fark saptanmadı. TARTIŞMA: Komplike olmayan akut apandisit tanısı alan hastaların, acil serviste ameliyat öncesi uygun medikal tedavi ve gözlem altında geçirdiği bekleme süresinin, komplikasyon ve hastanede yatış süresi üzerine olumsuz etkisi yoktur.

Anahtar sözcükler: Apandisit; gecikmiş apendektomi; komplike olmayan apandisit; medikal tedavi.

Ulus Travma Acil Cerrahi Derg 2020;26(5):742-745 doi: 10.14744/tjtes.2020.23236 